\title{
Photoinactivation of Candida albicans using methylene blue as photosensitizer
}

\author{
Fotoinativação de Candida albicans utilizando azul de metileno como fotossensibilizador ${ }^{1}$
}

João Nilton Lopes de SOUSA²

Bruna Honório de QUEIROGA ${ }^{3}$

Patrícia de Oliveira KOCERGINSKY ${ }^{4}$

Petrusk Homero Campos MARINHO ${ }^{4}$

Ângela Toshie ARAKI ${ }^{5}$

\section{ABSTRACT}

\section{Objective}

To evaluate the effect of photodynamic therapy in the inactivation of Candida albicans planktonic cells, using methylene blue, $150 \mathrm{mg} / \mathrm{mL}$, as a photosensitizer.

\section{Methods}

Aliquots of $100\left(\mu \mathrm{g} / \mathrm{mL}\right.$ of the fungal suspension in a $10^{6} \mathrm{cell} / \mathrm{s} / \mathrm{mL}$ concentration were seeded in microtiter plates with 96 wells, where the same volume of methylene blue was deposited, remaining for 5 min pre-irradiation. Then, the low power laser light was applied (wavelength: $660 \mathrm{~nm}$, power: $100 \mathrm{~mW}$ and dose: $426 \mathrm{~J} / \mathrm{cm}^{2}$ ) for 128s using a portable semiconductor laser. Control experiments were performed without illumination and in the absence of methylene blue, and another in the presence of methylene blue without illumination and with illumination, replacing the photosensitizer by saline. In each experimental condition, serial dilutions $\left(10^{-1}\right.$ to $\left.{ }^{10-3}\right)$ were obtained and $25 \mu \mathrm{L}$ aliquots were seeded in Sabouraud Dextrose Agar duplicate. After this period, the number of colony forming units per milliliter (CFU/mL) was determined and the data were submitted to variance analysis and Kruskal Wallis test $(p<0.05)$.

\section{Results}

At the concentration of $150 \mu \mathrm{g} / \mathrm{mL}$, and time of $5 \mathrm{~min}$ incubation, the reduction was significant (pख0.05). In the absence of irradiation, methylene blue produced no reduction in CFU/mL.

\section{Conclusion}

Photodynamic Therapy presented antifungal effect against Candida albicans and can be used as an adjunct to conventional treatment.

Indexing terms: Candida albicans. Methylene blue. Photochemotherapy.

\section{RESUMO}

\section{Objetivo}

Avaliar o efeito da terapia fotodinâmica na inativação de células planctônicas de Candida albicans, empregando azul de metileno a 150 ㅆg/ $\mathrm{mL}$ como fotossensibilizador.

\section{Métodos}

Alíquotas de $100 \mu \mathrm{g} / \mathrm{mL}$ da suspensão do fungo na concentração de $10^{6}$ células $/ \mathrm{mL}$ foram semeadas em placas de microtitulação com 96 pocos, onde foi depositado o mesmo volume de azul de metileno, permanecendo por um período de pré-irradiação de 5 min. Em seguida, aplicou-se luz laser de baixa potência (comprimento de onda: $660 \mathrm{~nm}$, potência: $100 \mathrm{~mW}$ e dose: $426 \mathrm{~J} / \mathrm{cm}^{2}$ ) por 128s, utilizando um Laser semicondutor portátil. Experimentos controles foram realizados, sem iluminação e na ausência de azul de metileno, outro na presença de azul de metileno sem iluminação e com iluminação, substituindo o fotossensibilizador por solução salina. De cada condição experimental, diluicões em série $\left(10^{-1}\right.$ a $\left.10^{-3}\right)$ foram obtidas e alíquotas de $25 \mu \mathrm{L}$ foram plaqueadas em duplicata em Agar Sabouraud Dextrose. Após este período, o número de unidades formadoras de colônias por mililitro (CFU/mL) foi determinado e os dados foram submetidos à análise de variância e teste de Kruskal Wallis $(p<0,05)$.

Resultados

Na concentração de $150 \mu \mathrm{g} / \mathrm{mL}$ e tempo de 5 min de incubação, a redução foi significativa $(p<0,05)$. Na ausência de irradiação, o azul de metileno não produziu redução de CFU/mL.

\section{Conclusão}

A Terapia Fotodinâmica apresentou efeito antifúngico contra Candida albicans, podendo ser utilizada como coadjuvante ao tratamento convencional.

Termos de indexação: Candida albicans. Azul de metileno. Fotoquimioterapia.

\footnotetext{
${ }^{1}$ Artigo baseado na tese intitulada "Inativação de células planctônicas de Candida albicans empregando terapia fotodinâmica". Universidade Cruzeiro do Sul; 2014.

${ }^{2}$ Universidade Federal de Campina Grande, Faculdade de Odontologia, Departamento de Periodontia. Av. Universitária, s/n, Patos, PB, Brasil, 58700970. Correspondência para / Correspondence to: JNL SOUSA. E-mail: <jnlopesodonto@gmail.com>.

${ }^{3}$ Universidade Federal de Campina Grande, Faculdade de Odontologia. Patos, PB, Brasil.

${ }^{4}$ Faculdades Integradas de Patos, Departamento de Biomedicina. Patos, PB, Brasil.

${ }^{5}$ Universidade Cruzeiro do Sul. São Paulo, SP, Brasil.
} 


\section{INTRODUCTION}

Opportunistic fungi can cause critical superficial or invasive infections in apparently healthy patients and especially in debilitated or immunocompromised patients. Due to difficulties in diagnosis and the limited availability of effective antifungal drugs, diseases caused by fungi represent a growing threat to human health, and can result in highly attributable mortality".

Candida albicans is an opportunistic fungus, which requires some predisposing factors for the disease development, such as immunosuppressive agents, use of broad-spectrum antibiotics, xerostomia, prosthetic use and poor oral hygiene. In patients with Acquired Immunodeficiency Syndrome (AIDS), the oral candidosis is the most common fungal manifestation, as an indicator of the infection progression².

According to Lam et al. ${ }^{3}$, the infections caused by fungi represent a critical challenge to public health with high socio-economic importance, mainly due to traditional antifungal resistant species, requiring the development of scientific research that seek to expand the lesions treatment forms, enabling the effective alternative treatment of failure cases and improving the well-being of patients affected by this disease.

Photodynamic Therapy (PDT) is a treatment already used in several medical specialties, such as dermatology, oncology and ophthalmology, and has been investigated as an antimicrobial therapy, which consists in the administration of a photosensitizing (FS) dye, followed by the lesion illumination with visible light, forming cytotoxic species in the presence of oxygen, such as the singlet oxygen and free radicals ${ }^{4}$. These reactive chemical species are mostly toxic and can cause: destruction of proteins, lipids, nucleic acids, and other cell components, resulting in the destruction of microbial cells ${ }^{5}$.

Photodynamic therapy offers antimicrobial action mechanisms different from antifungal drugs, which attenuates the resistance development cases, making this treatment modality an effective alternative against C. albicans strains resistant to conventional therapy ${ }^{6}$. The use of methylene blue in photodynamic therapy has shown effective results in Candida albicans inactivation, however, it is necessary to establish a suitable clinical protocol regarding the pre-irradiation time and the dye concentration, without toxic effects to the organism cells.
Therefore, this study aims to evaluate, in vitro, the photosensitizing effects in Candida albicans with laser radiation, using methylene blue as a photosensitizer.

\section{METHODS}

Candida albicans (ATCC 10231) strains were used, acquired from the tropical crops collection (CCT) of André Tosello Foundation. For the performing the experiments, the Agar Sabouraud Dextrose-ASD (União Química, São Paulo, Brazil) culture medium was used with $5 \mu \mathrm{g} / \mathrm{mL}$ chloramphenicol, as preconized in Pereira et al. ${ }^{7}$.

\section{Photosensitizer (FS) preparation and incubation time}

The FS agent used was methylene blue (AM) PA (Sigma-Aldrich, São Paulo, Brazil). Stock solutions from AM PA, at a concentration of $300 \mu \mathrm{g} / \mathrm{mL}$ were prepared by dissolving the powder in sterile saline solution $(0.85 \%$ $\mathrm{Na} \mathrm{Cl}$ ) at $\mathrm{pH} 7^{8}$. During the experiment, in microtiter plate wells, $100 \mu \mathrm{L}$ of FS stock solution, at room temperature, was again diluted by adding $100 \mu \mathrm{L}$ of Candida albicans suspension in saline solution $0.85 \%{ }^{9}$, resulting in a final volume of $200 \mu \mathrm{L}$. As the well volume is duplicated (100 $\mu \mathrm{L}$ of $\mathrm{FS}$ and $100 \mu \mathrm{L}$ of cell suspension), FS concentration is halved: $150 \mu \mathrm{g} / \mathrm{mL}$ (work concentration). Then, the AM dye was in contact with the Candida albicans cells, in the dark and at room temperature, before the illumination, for an incubation period of 5 minutes (pre-irradiation time). With this purpose, the plates were in an environment without luminosity and involved by an aluminum foil.

\section{Irradiation source for photodynamic therapy (PDT)}

The light source was a portable Semiconductor Laser (Laser DUO ${ }^{\circledR}$, GaAlAs, InGaAlP, $1880 \mathrm{~nm}$ and $\lambda 660 \mathrm{~nm}$, MM OPTICS Ltda., São Carlos, Brazil). This instrument features constant output power of $100 \mathrm{~mW}$ and the laser beam area of $3 \mathrm{~mm}^{2}$, which matches with the opening area of each of the $96 \mathrm{U}$-deep wells of the microtiter plates used in this study. For the irradiation protocol, the equipment was adjusted to a wavelength of $660 \mathrm{~nm}$, which corresponds to the AM absorption range, and to the illumination time of 128s, resulting in an energy influence of $426 \mathrm{~J} / \mathrm{cm}^{2}$. Prior to the experiments, the laser was calibrated using a device (Check MM OPTICS Ltda., São Carlos, Brazil). Before each irradiation, the instrument tip was immersed in chlorhexidine digluconate solution to $2 \%$ for 5 minutes to promote its disinfection. After this period, 
the antimicrobial agent was removed from the device by means of irrigation with $10 \mathrm{~mL}$ of saline solution $(0.9 \%)$ and dried with sterile gauze. The equipment tip was positioned perpendicular to the wells opening and the irradiation was carried out with $90^{\circ}$ incidence angle. In order to avoid a possible cumulative effect due to irradiation spreading, each sample was individually irradiated and collected ${ }^{9}$.

\section{Inoculum preparation of Candida albicans}

Candida albicans (ATCC 10-231) cells were sub cultivated from stocks flasks in Agar Sabouraud DextroseASD under aerobic conditions at $37^{\circ} \mathrm{C}$. After $24 \mathrm{~h}$ incubation, a sample of colonies was removed from the Agar plate surface and suspended in sterile saline solution $0.85 \%$ of $\mathrm{NaCl}^{10}$. After stirring using a Vortex device (Vision $\left.{ }^{\circledR}\right)$ for 2 minutes, the cell suspension turbidity was adjusted using a spectrophotometer to $530 \mathrm{~nm}$ to obtain suspensions with optical density of 0.284 , which corresponds to fungi concentration of $10^{6}$ colony forming units per $\mathrm{mL}(\mathrm{CFU} / \mathrm{mL})^{4,7,9}$.

\section{Experimental conditions}

All tested conditions were carried out in the dark at room temperature and under sterile conditions in a laminar flow chamber. Microtiter plates were covered with aluminum foils to prevent the environment light penetration.

\section{Photodynamic Therapy Group (PDT Group)}

In photodynamic therapy group, PDT group (FS+ $L+)$, Candida albicans strains were sensitized with the FS, methylene blue, and exposed to the laser (L). With constant stirring, $100 \mu \mathrm{L}$ aliquots of fungus suspension $\left(10^{6} \mathrm{CFU} /\right.$ $\mathrm{mL}$ ) were individually transferred to a microtiter plate well with 96 wells. Then, the same volume of AM $(100 \mu l)$ was added at the tested concentration $(300 \mu \mathrm{g} / \mathrm{mL})$, resulting in a final volume of $200 \mu \mathrm{L}$ per well and final concentration of $150 \mu \mathrm{g} / \mathrm{mL}$ (PDT AM group - $150 \mu \mathrm{g} / \mathrm{ml}$ ). Subsequently, the plates containing the resulting suspensions were left at rest, in the dark, during the incubation time of 5 minutes. After the pre-irradiation time, the plates were opened and yeast cells were continuously irradiated, from the top of the microtiter plate, with a diode laser (wavelength of $660 \mathrm{~nm}$; $100 \mathrm{~mW}$ power, and dose of $426 \mathrm{~J} / \mathrm{cm}^{2}$ ) for $128 \mathrm{~s}$. The wells content was duly homogenized before illumination and sampling.

\section{Methylene Blue Group (AM Group)}

In AM group, FS effect alone, on Candida albicans cells inactivation, was tested by applying the solution following the same protocol established for the PDT Group $(\mathrm{FS}+\mathrm{L}+)$, especially regarding the volume $(100 \mu \mathrm{L})$, tested concentration $(150 \mu \mathrm{g} / \mathrm{mL})$, and incubation time (5 min.) with the absence of light, but without the laser treatment. In this group, it was possible to evaluate the AM toxicity in Candida albicans cells.

\section{Laser Group (L Group)}

In the laser group, L group, Candida albicans strains were exposed to laser light $(\mathrm{L})$, but have not been sensitized by FS. With this group it was possible to evaluate the laser light effect in isolation on yeast cells inactivation. $100 \mu \mathrm{L}$ aliquots of cell suspension were individually transferred to one of the wells of a microtiter plate. Then, the same volume of sterile saline solution $0.85 \%$ was transferred to the well. The test system was kept in the dark by the same incubation time of the previous groups (5 min.).

\section{Saline solution group (SS Group)}

In the saline solution group, SS group, Candida albicans cells did not receive any treatment, i.e. were sensitized by FS, or exposed to light. $100 \mu \mathrm{L}$ aliquots of the suspension $\left(10^{6} \mathrm{CFU} / \mathrm{mL}\right)$ were transferred to the wells of a microtiter plate, and then, the same volume of saline solution $0.85 \%$ was deposited in the well and the plate was at rest in the dark by the same incubation time of previous groups (5 minutes). The results obtained with this sample cultures were used as parameter for comparison with those obtained with cultures of samples submitted to the experimental conditions.

\section{Viability evaluation of Candida albicans cells}

For all conditions evaluated, 1:3 serial dilutions were made from the samples contained in the plates' wells. For this, a $100 \mu \mathrm{L}$ aliquot was removed from each well and transferred to a test tube containing $900 \mu \mathrm{L}$ of sterile saline solution $(0.85 \%)$. This tube was vigorously stirred in a tube stirrer (Vortex-Vision ${ }^{\circledR}$ ) and a new aliquot of 100 $\mu \mathrm{L}$ was removed from it and put into another test tube containing $900 \mu \mathrm{L}$ of sterile saline solution. This procedure was performed three times for each sample and, therefore, serial dilutions from $10^{-1}$ to $10^{-3}$ were obtained. Serial dilutions $\left(10^{-1}, 10^{-2}\right.$ and $\left.10^{-3}\right)$ are used for the seeding in 
Petri dishes containing Agar Sabouraud Dextrose culture medium.

Then, $25 \mu \mathrm{L}$ aliquots of each serial dilution were pipetted in duplicate. Additionally, $25 \mu \mathrm{L}$ aliquots were removed from the plates well and directly transferred the Petri dishes, without dilution. A sterile Drigalsky handle was used to spread the solution over the culture medium on the plate. Also, the seeding procedures were performed in duplicate. After 48 hours of incubation at $37^{\circ} \mathrm{C}$, the Petri dishes related to the evaluated experimental conditions samples were submitted to the colonies count. For this procedure, the colonies quantification was performed and the numbers of colony-forming units of were calculated.

\section{CFU/mL Count Technique}

The plates reading was made by default count of Candida albicans colonies (Colony Forming Unit - CFU/mL) using a colony counter. For the counting, plates containing a number of colonies that was within the accuracy and repeatability range from 30 to 300 colonies were selected. For each dilution $\left(10^{-1} ; 10^{-2}\right.$ and $\left.10^{-3}\right)$, the colonies number results was obtained by the arithmetic mean of the duplicate plates results and multiplied by the corresponding dilution $(10,100$ or 1000). The result of each group was found by using the arithmetic mean of the three dilutions. Then, to find the CFU number per $\mathrm{mL}$, the result of each group was converted from the inoculated amount of $25 \mu \mathrm{L}$ to 1 $\mathrm{mL}$, dividing the result by 0.025 , getting the final result of CFUs/mL in the potency of 10 . For the CFU/mL count analysis of Candida albicans, it was decided to transform values into potency of 10, using the decimal logarithm of this number for the statistical analysis.

In situations where all the plates showed less than 30 colonies, the result was expressed by the number of colonies of the lesser dilution plate. When all the plates showed more than 300 colonies in the greater dilution and it was possible to perform the count, the result was found by multiplying the value in the colonies number in each plate by the respective dilutions, and then, calculating the arithmetic mean. When the number of colonies was excessively high to count, a representative portion of the colonies distribution across the plate was chosen and the number of colonies present was estimated.

\section{Statistical analysis}

The $\log _{10}(\mathrm{CFU} / \mathrm{mL})$ results for each tested condition was compared using Kruskal-Wallis statistical test and in the case of a significant difference, multiple comparisons of such test were used. P values less than 0.05 were considered significant. The choice of Kruskal-Wallis test was due to the number of groups. The data were entered in the EXCEL spreadsheet and the software used to obtain the statistical calculations was the Trial version in Portuguese. The results of this research were expressed through the statistical measures: mean, standard deviation (SD), and median.

\section{RESULTS}

According to table 1 , it can be noticed that in 5-minutes incubation, the group irradiated with laser light, associated with the concentration of $150 \mu \mathrm{g} / \mathrm{mL}$ of methylene blue as photosensitizer (PDT AM group), showed a lower mean in the $\log _{10} C F U / m L$ value, $p=0.019$, showing inhibitory effect in Candida cells, compared to other groups, which showed no inhibitory effect of Candida Albicans cells. When comparing the $\mathrm{CFU} / \mathrm{mL}$ count results among the groups that assessed the methylene blue (AM Group) toxicity in the dark and light in the dose used (Laser group), with the group that received no treatment (Saline solution group), it was observed that only the AM or only the light did not exercise inhibitory effect against Candida albicans cells.

Table 1. Mean and standard deviation comparison of $\log _{10} \mathrm{CFU} / \mathrm{mL}$ among groups at 5-min. pre-irradiation time. Patos-PB, 2014.

\begin{tabular}{|c|c|}
\hline GROUPS & Mean \pm DP (Median) of $\log _{10} C F U / m L$ \\
\hline Saline solution & $5.51 \pm 0.67(5.60)^{(A)}$ \\
\hline Laser & $5.57 \pm 0.71(5.69)^{(A)}$ \\
\hline AM $150 \mu \mathrm{g} / \mathrm{ml}$ & $5.64 \pm 0.77(5.76)^{(\mathrm{A})}$ \\
\hline PDT - AM $150 \mu \mathrm{g} / \mathrm{ml}$ & $2.10 \pm 2.42(2.04)^{(B)}$ \\
\hline$p$-value & $\mathrm{p}^{(1)}=0.019^{*}$ \\
\hline
\end{tabular}

\section{DISCUSSION}

The light therapeutic properties studies with antimicrobial purpose are primarily motivated by resistance cases of conventional antimicrobia|3,6,11-14. The need to overcome these deficiencies led to the exploration of 
alternative treatments and unconventional approaches to the control of microbial infections ${ }^{14}$.

Currently, the light-based antimicrobial treatment is called Photodynamic therapy ${ }^{4-5,15}$. The three main components of PDT are visible light, FS and oxygen ${ }^{16}$. Due to the fact that they absorb light with high efficiency, in some region of the visible spectrum, some of the FSs are able to induce or participate in photochemical reactions and produce reactive oxygen molecules 5, 14,17-18

Several studies that evaluated azole-resistant Candida species, noted that these strains were sensitive to PDT11-12,19-20. The photosensitizer and light application specifically on the site affected by candidiasis, dramatically reduces the local and systemic side effects, allowing the photodynamic therapy to be seen as a promising treatment against Candida albicans ${ }^{21}$.

The light sources used more often in PDT against Candida albicans were LED ${ }^{12}$ and the low-intensity laser, highlighting the diode laser ${ }^{6,8-9,10,22}$. In this research, diode laser of MM OPTICS (Laser DUO ${ }^{\circledR}$ ) was used and, due to being portable and having batteries, this presents a greater advantage compared to the handling without relying on an energy source, and can be applied to patients in several environments: domestic, clinic, family health care units, or intensive care units.

Methylene blue was the photosensitizer used in this study because it is a low toxicity dye with high visible light absorption at wavelengths greater than $620 \mathrm{~nm}^{6}$. It is used with different purposes in microbiology and pharmacology for quite some time and, lately, has been applied on PDT as a photosensitizing drug in association with a continuous light source. So that the photosensitizer can be one light-activated by laser, the light applied must present a specific wavelength ${ }^{6,20}$. In this study, the red light with a wavelength of $660 \mathrm{~nm}$ was used, corresponding to the absorption spectrum of methylene blue, and was adjusted to the appliance before illumination.

The studies of Dai et al. ${ }^{1}$, Kato et al. ${ }^{4}$, Teichert et al. ${ }^{6}$, Pereira et al. ${ }^{7}$, Souza et al. ${ }^{8}$, Queiroga et al. ${ }^{9}$, Munin et al. ${ }^{10}$, Silva Martins et al. ${ }^{17}$, Giroldo et al. ${ }^{22}$ and Souza et al. ${ }^{23}$, investigated the effects of photodynamic therapy on the viability of Candida albicans using methylene blue as a photosensitizer. The results of these studies proved the antifungal effect of this treatment modality. However, some points still needed to be better clarified, before recommending it for clinical therapy. There is need to establish protocols with well-defined parameters, such as the appropriate dosimetry of FS and light, and the time in which the dye must remain in contact with the microorganism ${ }^{13}$.

The experimental model chosen was microtiter plates with $96 \mathrm{U}$-deep wells. This methodology has been widely used in researches that assessed the antimicrobial effect of PDT on microorganism in plankton form from a cell suspension ${ }^{9,10,23}$

The photo-dynamic effect depends on the FS concentration used, combined with irradiation parameters that activate the dye ${ }^{4,15}$. The studies that evaluated PDT effect on Candida albicans used different concentrations of methylene blue, from $10 \mu \mathrm{g} / \mathrm{mL}^{22}$ to $500 \mu \mathrm{g} / \mathrm{mL}^{6}$ and the most used incubation time was 5 minutes ${ }^{7-9}$. Therefore, to respond to the PDT effect hypothesis on the Candida albicans cells, this study used the concentration of $150 \mu \mathrm{g} /$ $\mathrm{mL}$ and the incubation time of 5 minutes.

The fact that most FSs are both fluorescent and photochemically active, allows that various strategies and protocols can be combined in photodynamic therapy. The most important factor governing the PDT results is how the FS interacts with the cells in the tissue or target lesion, and the key aspect of this interaction is related to the FS intracellular location. The incubation time is required to allow the drug to be absorbed by the microorganism and accumulate in the cell structures ${ }^{20}$, such as mitochondria, lysosomes, endoplasmic reticulum, Golgi apparatus and plasma membrane ${ }^{3}$. During irradiation, it is necessary that FS is already located inside the cell, because the singlet oxygen, formed after light application, presents minimal diffusion $(100 \mathrm{~nm})$ and cytotoxic effect only in the place where it is produced ${ }^{15}$.

As observed in Souza et al. ${ }^{8}$ and Queiroga et al. ${ }^{9}$ studies, laser light irradiation of Candida albicans, in the absence of $A M$, showed no influence on the microorganisms' viability. In the absence of light, methylene blue showed no cytotoxic effect on Candida albicans cells, corroborating with the aforementioned studies. Both the photosensitizer and the light are relatively harmless by itself, but when combined, in the presence of oxygen, cause selective destruction on the affected area ${ }^{17,22}$. According to Pereira \& Maisch ${ }^{14}$ and Ryskova et al. ${ }^{15}$ photosensitizing agents show no or minimal inherent toxicity and the cytotoxic effect only occurs after its illumination with specific wavelength light.

In the concentration of $150 \mu \mathrm{g} / \mathrm{mL}$, the CFU/ $\mathrm{mL}$ reduction was significant at 5-minutes incubation, compared to control groups, stating that the photodynamic therapy had effect on the cells. Therefore, according to this 
study parameters and the cost-benefit ratio regarding the drug concentration and the clinical procedure time, the PDT protocol proved effective when used the 5-minutes incubation and the methylene blue concentration of 150 $\mu \mathrm{g} / \mathrm{mL}$. Using the 5-minutes incubation and methylene blue concentrations of $100 \mu \mathrm{g} / \mathrm{mL}, 150 \mu \mathrm{g} / \mathrm{mL}$ and $50 \mu \mathrm{g} /$ $\mathrm{mL}$, Pereira et al. ${ }^{7}$, Queiroga et al. ${ }^{9}$ and Giroldo et al. ${ }^{22}$, respectively, observed a significant reduction in cell viability of Candida albicans species.

While evaluating the studies that have applied the methylene blue as a photosensitizer, a great shortage of controlled and randomized clinical trials, using antifungal treatment against Candida albicans by photodynamic therapy was noticed, which, despite the animal and in vitro studies being very promising, it makes the clinical indication of this therapy on scientific evidence-based Dentistry impracticable. Therefore, photodynamic therapy still requires that clinical trials are designed to give it support and therapeutic applicability.

The limitation of this study was the fact that it only used a single species of Candida and only one concentration of methylene blue. However, this methodology has met the experiment initial objectives. Other studies may be developed using this method to evaluate the PDT effect against all species of Candida or a clinical trial testing

\section{REFERENCES}

1. Dai T, Arce VJB, Tegos GP, Hamblin MR. Blue dye and red light, a dynamic combination for prophylaxis and treatment of cutaneous Candida albicans infections in mice. Antimicrob Agents Chemother. 2011;55(12):5710-7. doi: 10.1128/AAC.05404-11

2. Naglik JR, Paul L, Fidel PLJ, Odds FC. Animal models of mucosal Candida infection. National Institutes of Health. 2008;283(2):1299. doi: 10.1111/j.1574 6968.2008.01160.x

3. Lam M, Jou PC, Lattif AA, Lee $Y$, Malbasa CL, Mukherjee PK, et al. Photodynamic therapy with Pc 4 induces apoptosis of Candida albicans. Photochem Photobiol. 2011;87(4):904-9. doi: 10.1111/j.1751-1097.2011.00938.x

4. Kato TI, Prates RA, Sabino CP, Fuchs BB, Tegos GP, Mylonakis E, et al. Antimicrobial photodynamic inactivation inhibits Candida albicans virulence factors and reduces in vivo pathogenicity. Antimicrob Agents Chemother. 2013;57(1):445-51. doi: 10.1128/ AAC.01451-12

5. Kopnopka K, Goslinski T. Photodynamic therapy in dentistry. J Dent Res. 2007;86(8):694-707. doi: 10.1177/154405910708600803

6. Teichert MC, Jones JW, Usacheya MN, Biel MA. Treatment of oral candidiasis with methylene blue-mediated photodynamic therapy in an immunodeficient murine model. Oral Surg Oral Med Oral different concentrations of methylene blue and different incubation times.

\section{CONCLUSION}

It was concluded that the methylene blue photosensitizer showed no cytotoxicity in the dark on Candida albicans, and also the laser light has not altered the microorganism cell viability in the photosensitizer absence. And that the photodynamic therapy decreased the CFU/mL number of Candida albicans, showing satisfactory antifungal effect against this microorganism. The 5-minutes incubation presented effective results reducing the $\log _{10} \mathrm{CFU} / \mathrm{mL}$ number.

\section{Collaborators}

JNL SOUZA and BH QUEIROGA substantially contributed to the design and planning, analysis and interpretation of the data and content, and the paper writing. PO KOCERGINSKY and PHC MARINHO significantly contributed in microbiological experiments, and in the paper writing. ÂT ARAKI significantly contributed in the paper preparation and writing.

Pathol Oral Radiol Endod. 2002;93(2):155-60. doi: 10.1067/ moe.2002.120051

7. Pereira CA, Romeiro RL, Costa AC, Machado AK, Junqueira JC, Jorge AO. Susceptibility of Candida albicans, staphylococcus aureus, and streptococcus mutans biofilms to photodynamic inactivation: an in vitro study. Lasers Med Sci. 2011;26(3):341348. doi: 10.1007/s10103-010-0852-3.

8. Souza SC, Junqueira JC, Balducci I, Koga-ito CY, Munin E, Jorge AO. Photosensitization of different candida species by low power laser light. J Photochem Photobiol. B. 2006;83(1):34-8. doi:10.1016/j.jphotobiol.2005.12.002

9. Queiroga AS, Trajano VN, Lima EO, Ferreira AF, Limeira FA. J. In vitro photodynamic inactivation of candida spp. by different doses of low power laser light. Photodiagnosis Photodyn Ther. 2011;8(4):332-6. doi: 10.1016/j.pdpdt.2011.08.005.

10. Munin E, Giroldo LM, Alves LP, Costa MS. Study of germ tube formation by candida albicans after photodynamic antimicrobial chemotherapy (PACT). J Photochem Photobiol. B. 2007;88(1):1620. doi:10.1016/j.jphotobiol.2007.04.011

11. Donnely RF, Mccarron PA, Tunney MM. Antifungal photodynamic therapy. Res Microbiol. 2008;163(1):1-12. doi: 10.1016/j. micres.2007.08.001

12. Dovigo LN, Pavarina AC, Carmello JC, Machado AL, Brunetti IL, Bagnato VS. Susceptibility of clinical isolates of candida 
to photodynamic effects of curcumin. Lasers Surg Med. 2011;43(9):927-34. doi: 10.1002/lsm.21110

13. Kharkwal GB, Sharma SK, Huang YY, Dai T, Hanblin MR. Photodynamic therapy for infections: clinical applications. Lasers Surg Med. 2011;43(7):755-67. doi: 10.1002/lsm.21080

14. Pereira FG, Maisch T. Photodynamic inactivation to control infections caused by Candida albicans. Fungal Biol. 2012:116(1):1-10. doi: 10.1128/AAC.01451-12

15. Ryskova L, Buchta V, Slezak R. Photodynamic antimicrobial therapy. Cent Eur J Biol. 2010;5(4):400-406. doi: 102478/ s11535-010-0032-2

16. Dai T, Fuchs BB, Coleman JJ, Prates RA, Astrakas C, Denis TG, et al. Concepts and principles of photodynamic therapy as an alternative antifungal discovery platform. Front Microbiol. 2012;3(120):1-16. doi: 10.3389/fmicb.2012.00120

17. Silva Martins J, Junqueira JC, Faria RL, Santiago NF, Rossoni RD Colombo CE, et al. Antimicrobial photodynamic therapy in rat experimental candidiasis: evaluation of pathogenicity factors of candida albicans. Oral Surg Oral Med Oral Pathol Oral Radiol Endod. 2011;111(1):71-7. doi: 10.1016/j.tripleo.2010.08.012

18. Huang L, Xuan Y, Koide $Y$, Zhiyebtayev T, Tanaka M, Hamblin MR. Type I and type II mechanisms of antimicrobial photodynamic therapy: an in vitro study on gram-negative and gram-positive bacteria. Lasers Surg Med. 2012:44(6):490-9. doi: 10.1002/ Ism.22045
19. Mang TS, Mikulski L, Sala RE. Photodynamic inactivation of normal and antifungal resistant candida species. Photodiagnosis Photodyn Ther. 2010;7(2):98-105. doi: 10.1016/j. pdpdt.2010.03.001

20. Lyon JP, Moreira LM, Moraes PC, Santos FV, Resende MA. Photodynamic therapy for pathogenic fungi. Mycoses. 2011;54(5):265-71. doi: 10.1111/j.1439-0507.2010.01966.x

21. Chien HF, Chen $C P$, Chen YC, Chang PH, Tsai $T$, Chen $C Y$. The use of chitosan to enhance photodynamic inactivation against candida albicans and its drug-resistant clinical isolates. Int J Mol Sei. 2013;14(4):7.445-7.456. doi: 10.3390/ijms14047445

22. Giroldo LM, Felipe MP, Oliveira MA, Munin E, Alves LP, Costa MS. Photodynamic antimicrobial chemotherapy (PACT) with methylene blue increases membrane permeability in candida albicans. Lasers Med Sci. 2009;24(1):109-12.

23. Souza RC, Junqueira JC, Rossoni RD, Pereira CA, Munin E, Jorge AO. Comparison of the photodynamic fungicidal efficacy of methylene blue, toluidine blue, malachite green and low-power laser irradiation alone against candida albicans. Lasers Med Sci. 2010:25(3):385-9. doi: 10.1007/s10103-009-0706-z

Received on: 17/3/2015

Final version resubmitted on: 27/4/2015

Approved on: 11/5/2015 